\title{
IMPLEMENTASI ETIKA BISNIS ISLAM DALAM PENGELOLAAN HCG (HIKMA COLLECTION GROUP) DI PONDOK PESANTREN MIFTAHUL HIKMAH KARANG KECAMATAN PARENGAN KABUPATAN TUBAN
}

\author{
Oleh: \\ Mela Anggilia, Joko Hadi Purnomo \& Niswatin Nurul Hidayati \\ Institut Agama Islam Al Hikmah Tuban \\ journal.sharia.economics@gmail.com,joko.hpurnomo@gmail.com, \\ niswatinnh@gmail.com
}

\begin{abstract}
:
The purpose of this study is to describe and analyze the implementation of Islamic business ethics in the management of HCG (Hikma Collection Group) at Miftahul Hikmah Parengan Tuban, as well as the obstacles faced. This study used qualitative research methods. The results of this study are the implementation of Islamic business ethics in the management of HCG (Hikma Collection Group) using eight principles that are in accordance with Islamic teachings, namely the first with the principle of honesty in business, the second with the principle of selling good quality goods. The third principle is not selling out promises to consumers who want to buy at HCG (Hikma Collection Group). The fourth principle applied in HCG (Hikma Collection Group) is to be responsible in doing business regarding dissatisfaction in front of consumers and being responsible before God. The fifth principle is nonbinding and generous to customers and all employees by getting used to being polite, smiling, greeting and friendly to all consumers and each employee. The sixth principle is the balance of doing business by always prioritizing the unity of every employee in HCG (Hikma Collection Group). The seventh principle is discipline in administration that uses honesty and timeliness in completing administrative reports. The last principle is to complete the product according to the target desired by the consumer. In addition, there are also several supporting and inhibiting factors in the implementation of Islamic business ethics in the institution.
\end{abstract}

Keywords: Etika Bisnis Islam, Bisnis, Pengelolaan Bisnis, Pesantren, Tuban 


\section{A. Pendahuluan}

Dunia bisnis mengalami perkembangan yang semakin pesat apalagi didukung oleh berbagai sistem teknologi informasi yang berkembang pesat. Di dalam era bisnis saat ini sering dijadikan alat untuk melakukan kecurangan dalam berbisnis. Untuk itu adanya etika bisnis digunakan sebagai pengendali perilaku persaingan bisnis agar sesuai dengan norma yang ada. Beberapa manusia lebih memilih bisnis untuk memenuhi kebutuhannya yang tidak terbatas. Aktivitas bisnis sangat diperlukan karena manusia adalah makhluk sosial yang tidak mampu memenuhi kebutuhannya sendiri tanpa bantuan orang lain.

Bisnis merupakan bagian dari muamalah. Hal tersebut dikarenakan bisnis tidak terlepas dari hukum-hukum yang juga mengatur masalah muamalah. Oleh karena itu, adanya persaingan bebas yang mengahalalkan segala cara dalam berbisnis merupakan praktik yang harus dihilangkan karena bertentangan dengan prinsip-prinsip muamalah dalam Islam. ${ }^{1}$ Islam memberikan batasan atau pemisah antara yang boleh dan yang tidak boleh, antara yang benar dan yang salah yakni dengan adanya istilah etika. Dalam menjalankan aktivitas yang berhubungan dengan usaha tentu perlu adanya etika karena untuk mengatur berlangsungnya kegiatan tersebut, jadi semua pihak merasa tenang dengan adanya etika bisnis. Etika adalah ilmu tentang apa yang baik dan apa yang buruk dan tentang hak dan kewajiban moral (akhlak). ${ }^{2}$ Bisnis menurut Hughes dan Kapoor adalah suatu kegiatan usaha individu yang terorganisasi untuk menghasilkan (laba) atau menjual barang dan jasa guna mendapatkan

keuntungan dalam memenuhi kebutuhan masyarakat. ${ }^{3}$ Sedangkan Islam dapat dijelaskan sebagai suatu agama yang mengatur seluruh aktivitas manusia baik dunia duniawi ataupun akhirat. Sedangkan makna dari Etika bisnis Islam adalah akhlak dalam menjalankan bisnis sesuai dengan nilainilai Islam, sehingga dalam melaksanakan bisnisnya tidak perlu ada kekawatiran, sebab sudah diyakini sebagai suatu yang baik dan benar, ${ }^{4}$ bisnis yang sehat adalah bisnis yang berlandaskan pada etika. ${ }^{5}$ Berbisnis

1 Veithzal Rivai Zainal, dkk. Islamic Marketing Management, (Jakarta: PT. Bumi Aksara, 2017), 294.

2 Veithzal Rivai dan Antoni Nizar Usman, Islamic Economics and Finance: Ekonomi dan Keuangan Islam Bukan Alternatif, tetapi Solusi (Jakarta: Gramedia Pustaka Utama, 2012), 215.

3 Muhammad dan R. Lukman Fauroni, Visi Al-Qur'an tentang Etika dan Bisnis (Jakarta: Salemba Diniyah, 2002), 60-61.

${ }^{4}$ Ali Hasan, Manajemen Bisnis Syari'ah (Yogyakarta: Pustaka Pelajar, 2009), 171.

5 Muhammad dan R. Lukman Fauroni, Visi Al-Qur'an tentang Etika dan Bisnis

$266 \mid$ JURNAL LISAN AL-HAL 
secara etis sangat perlu dilakukan karena profesi bisnis pada hakekatnya adalah profesi luhur yang melayani masyarakat banyak. Usaha bisnis berada di tengah-tengah masyarakat, mereka menjaga kelangsungan hidup bisnisnya. Caranya ialah menjalankan prinsip etika bisnis. ${ }^{6}$

Penerapan etika bisnis Islam tersebut juga harus mampu dilaksanakan dalam setiap aspek perekonomian termasuk dalam penyelenggaraan produksi, konsumsi maupun distribusi. Tidak terkecuali penerapan etika bisnis Islam dalam pengelolaan HCG (Hikma Collection Group) Miftahul Hikmah Karang, Sukorejo, Parengan, Tuban ini. HCG (Hikma Collection Group) adalah sebuah bisnis konveksi yang menjalankan dua usaha berupa menjahit dan menyablon. Usaha ini berdiri pada tahun 2016 dan berada di dalam pimpinan pondok pesantren Miftahul Hikmah yang didirikan oleh KH. Miftahul Asror pada tahun 2010. Dalam beberapa analisis data yang diperoleh peneliti bahwa, pondok pesantren Miftahul Hikmah ini menerapkan beberapa kegiatan yang dapat membentuk karakter santri yang berakhlahul karimah. ${ }^{7}$ Karena SDM yang ada di $H C G$ (Hikma Collection Group) ini keseluruan dari kalangan santri, maka dalam bisnisnya sangat memperhatikan sisi keagamaan dari setiap kegiatan pengelolaannya. Hal ini dilakukan untuk meningkatkan kualitas hubungan sang pencipta.

HCG (Hikma Collection Group) mempunyai beberapa peraturan yang telah dibuat oleh ketua bersama pengasuh pondok pesantren berupa Standard Operational Prosedure (SOP), Karena sistem pengelolaannya itu tetap berada di bawah naungan pondok pesantren. Tentu saja Standard Operational Prosedure (SOP) yang ada ini tidak akan melanggar peraturan pondok pesantren. Pada umumnya pondok pesantren itu pasti memiliki peraturan masing-masing sesuai dengan kesepakatan dari pendiri dan pengasuhnya, ${ }^{8}$ serta di pondok pesantren itu sudah pasti segala jenis peraturannya sesuai dengan yang diajarkan oleh Agama Islam.

Pembentukan karakter yang berakhlahul karimah ini berpengaruh pada penerapan etika bisnis syari'ah dalam pengelolaan HCG (Hikma Collection Group) berdasarkan nilai Islam. Namun berpegang pada prinsip syari'ah ditengah zaman moderen yang semakin maju ini menjadi sebuah

(Jakarta: Salemba Diniyah, 2002), 60-61.

6 Buchari Alma dan Donni Juni Priansa, Manajemen Bisnis Syariah (Bandung: Alfabeta, 2009), 200.

${ }^{7}$ Hasil Wawancara kepada ketua HCG (Hikma Collection Group) Miftahul Hikmah sokorejo, parengan, Tuban, Jum'at 19 Desember 2019, Pukul 10.00-10.30.

8 Abdurrahman Wahid, Menggerakkan Tradisi. (Yogyakarta: LKis, 2001) 100. 
tantangan bagi pemimpin usaha yang sedang berkembang. Pada dasarnya ajaran Islam memuat tiga pilar substansial yaitu akidah, ibadah dan akhlaq.

Islam adalah agama fitrah, yang diturunkan Allah sebagai agama petunjuk dan pengarah bagi manusia untuk menjalankan agama yang benar. Secara fitrah juga manusia dilahirkan dengan pembawaan karakter dan keyakinan yang bersifat monoteisme atau mengesakan Allah, yang kemudian berimbas pada bentuk peribadatan atau penghambaan kepada Nya, lalu berujung pada terbentuknya akhlaqul karimah yang dapat membawa kedamaian dan kasih sayang bagi alam semesta atau yang biasa dikenal dengan sebutan rahmatan lil'alamin. ${ }^{9}$ Selain dari tiga pilar etika bisnis tersebut terdapat penjelasan yang lebih terperinci dari pendapat Muhammad Djakfar terdapat 7 prinsip etika bisnis Islam yang harus dijalankan umat manusia, yakni: jujur dalam takaran (quantity), menjual barang yang baik mutunya (quality), dilarang menggunakan sumpah (alqasm), longgar dan bermurah hati (tatsamuh dan taraahum), membangun hubungan baik, tertib administrasi dan menetapkan harga dengan transparan. ${ }^{10}$ Ketujuh prinsip tersebut harus dilaksanakan agar usaha yang dijalankan dapat mendapatkan ridho dan barokah dari Allah SWT.

Sedangkan dari hasil observasi yang dilakukan penulis selama tujuh hari di Pondok Pesantren Miftahul Hikmah perilaku dan kode etik pengelolaan usaha pada HCG (Hikma Collection Group) Miftahul Hikmah Karang terdapat beberapa penerapan etika bisnis tenaga kerja yang berbeda dari prinsip-prinsip syari'at tersebut. hal ini tentu menjadikan alasan penulis untuk menggali lebih dalam tentang bagaimanakah implementasi etika bisnis syari'ah yang sudah diterapkan di HCG (Hikma Collection Group) dalam pengelolaannya, serta apa saja faktor pendukung dan penghambat dalam penerapan etika bisnis syari'ah tersebut.

\section{B. Kajian Teori}

\section{Pengertian Etika}

Etika atau moral dalam Islam merupakan buah dari keimanan, keislaman dan ketakwaan yang didasarkan pada keyakinan yang kuat pada kebenaran Allah Swt. Islam diturunkan Allah pada hakikatnya adalah untuk memperbaiki akhlak atau etika yang baik. Untuk maksud itu, Allah

$$
10 .
$$

${ }^{9}$ Tim DPPAI, Pilar Substansial Islam, Cetakan Ketiga, DPPAI UII, Yogyakarta, 2016,

${ }^{10}$ Muhammad Djakfar, Etika Bisnis Menangkap Sepirit Ajaran Langit dan Pesan Moral Ajaran Bumi, (Jakarta: Penebar Plus, 2012), 34.

$268 \mid$ JURNAL LISAN AL-HAL 
Swt dengan kasih-Nya menurunkan dan mengutus Rasulullah Saw yang merupakan contoh teladan yang paling baik (uswatun hasanah). Etika berasal dari bahasa Yunani, yaitu ethos yang berarti adat, watak atau kesusilaan. Dalam perkembangannya, istilah ini menjadi bidang kajian filsafat etik (ethics) yang menyelidiki dan mengkaji secara sistematis tentang moralitas. Dalam Islam, etika disamakan dengan ilmu akhlak. Keduanya menunjuk pada kajian moral. Namun, akhlak yang dimaknai sebagai tindakan moral sering juga disepadankan dengan istilah etika. Jadi, etika berarti tindakan moral maupun kajiannya.

Menurut Satyanugraha dalam buku Etika Bisnis: Prinsip Dan Aplikasi mendefinisikan etika sebagai nilai-nilai dan norma moral dalam suatu masyarakat. Etika sebagai ilmu juga dapat diartikan pemikiran moral yang mempelajari tentang apa yang harus dilakukan atau yang tidak boleh dilakukan. Sedangkan menurut Issa Rafiq Beekun etika dapat didefinisikan sebagai seperangkat prinsip moral yang membedakan yang baik dari yang buruk.

Adapun tema yang berhubungan dengan etika dalam Al-Qur'an yang secara langsung adalah al-khuluq. Al-khuluq dari kata dasar khaluqakhuluqan, yang berarti tabiat, budi pekerti, kebiasaan, kesatriaan, keprawiraan. Kata dasar khuluq yaitu khuluqa sangat berdekatan sekali dengan kata dasar khalaqa-khalqan yang berarti menjadikan, menciptakan. Dari kata khalaqa berubah-rubah dalam bentuknya menjadi al-khaliq yang menciptakan dan al-makhluq yang diciptakan. Sedangkan dari khaluqa-khuluq perubahannya menjadi alakhlaq yang kemudian dikenal menjadi sebuah ilmu yang berdiri sendiri.

Jadi, dapat disimpulkan bahwa pengertian etika secara umum adalah suatu peraturan atau norma yang bisa digunakan sebagai acuan bagi perilaku seseorang yang berkaitan dengan sifat yang baik dan buruk yang dilakukan oleh seseorang serta merupakan suatu kewajiban dan tanggungjawab moral. Dengan beberapa teori penulis mengambil dari pendapat Issa Rafiq Beekun sebagai teori utama karena lebih khusus mengarah kepada prinsip-prinsip moral yang harus diterapkan dalam sebuah bisnis, sedangkan teori lain sebagai pendukung dari teori utama.

\section{Pengertian Bisnis}

Kata bisnis dalam Al-Qur'an biasanya digunakan al-tijarah, al-ba'i, tadayantum, dan isytara. Tetapi yang seringkali digunakan adalah altijarah yang bermakna berdagang atau berniaga. Bisnis dapat diartikan dengan usaha yang dilakukan perusahaan dengan menyediakan produk 
barang atau jasa dengan tujuan memperoleh nilai lebih atau laba. Bisnis dalam Al-Qur'an dijelaskan melalui kata tijarah, yang mencakup dua makna yaitu: pertama, perniagaan secara umum yang mencakup perniagaan antara manusia dengan Allah. Ketika seorang

memilih petunjuk dari Allah, mencintai Allah dan Rasul-Nya, berjuang di jalan-Nya dengan harta dan jiwa, membaca kitab Allah, mendirikan shalat, menafkahkan sebagian rizqinya. Maka itu adalah sebaik-baik perniagaan antara manusia dengan Allah. Dalam salah satu ayat Al-Qur'an dijelaskan bahwa ketika seseorang membeli petunjuk Allah dengan kesesatan, maka ia termasuk seseorang yang tidak beruntung. ${ }^{11}$

Menurut Adam Smith, pertukaran dagang terjadi karena satu orang memproduksi lebih banyak barang tertentu sementara ia sendiri membutuhkan barang lain yang tidak bisa dibuatnya sendiri. Dengan kata lain, tujuan utama bisnis sesungguhnya bukan untuk mencari

keuntungan melainkan untuk memenuhi kebutuhan hidup orang lain, dan melalui kegiatan tersebut bisa memperoleh apa yang dibutuhkannya. Matsushita mengatakan bahwa tujuan bisnis sebenarnya bukanlah mencari keuntungan melainkan untuk melayani kebutuhan masyarakat. Sedangkan keuntungan tidak lain hanyalah simbol kepercayaan masyarakat atas kegiatan bisnis suatu perusahaan.

Jadi, dapat disimpulkan bahwa bisnis tidak akan pernah luput dari aktivitas untuk mengingat Allah. Sehingga diharapkan hal ini bisa menjadi suatu kontrol bagi seorang peniaga dan pengusaha, agar selalu berbuat kebaikan dan menjauhi perilaku yang merugikan dalam

suatu aktivitas bisnis. Dalam hal ini penulis mengambil teori terkait pengertian bisnis yang bersumber dari Al-Qur'an karena dalam Al-Qur'an dijelaskan terkait pelaksanaan bisnis yang sesuai dengan ajaran Islam dan lebih mencangkup seluruh aktivitas prekonomian. Sedangkan yang teori dari beberapa ilmuan hanya sebagai pendukung dari teori utama.

\section{Etika Bisnis}

Menurut Solihin Ismail menyebutkan bahwa etika bisnis merupakan penerapan etika secara umum terhadap pelaku bisnis. Secara lebih khusus lagi makna etika bisnis menunjukkan perilaku etis maupun tidak etis yang dilakukan oleh manajer dan karyawan dari sutau organisasi perusahaan. ${ }^{12}$ Jadi, dapat disimpulkan bahwa etika bisnis

11 Ika Yunia Fauzia, Etika Bisnis dalam Islam, (Jakarta: Prenada media Group, 2013), 6.

12 Ismail Solihin, Pengantar Bisnis: Pengenalan Praktik dan Studi Kasus, (Jakarta:

$270 \mid$ JURNAL LISAN AL-HAL 
merupakan cara-cara saat melakukan kegiatan berbisnis yang mencakup semua aspek, baik itu yang berkaitan dengan seseorang individu, perusahaan maupun masyarakat. Dengan memilih teori utama yang akan digunakan penulis terkait etika bisnis dari pendapat Solihin Ismail karena lebih luas penjelasannya dari pada teori yang dimiliki Freed R.David lebih singkat namun bermakna ini akan menjadi teori pendukung.

\section{Etika Bisnis dalam Perspektif Islam}

Etika bisnis Islam adalah sejumlah perilaku etis bisnis (akhlaq al islamiyah) yang dibungkus dengan nilai-nilai syariah yang mengedepankan halal dan haram. Perilaku yang etis yakni perilaku yang mengikuti perintah Allah dan menjauhi larangan-Nya.

Sedangkan menurut Djakfar, etika bisnis Islam adalah norma-norma etika yang berbasiskan al-Qur'an dan Hadits yang harus dijadikan acuan oleh siapapun dalam aktivitas bisnis. ${ }^{13}$

Dalam islam, etika bisnis Islam menuntut dan mengarahkan kaum muslimin untuk melakukan tindakan sesuai dengan apa yang dibolehkan dan dilarang oleh Allah Swt termasuk dalam melaksanakan aktivitas ekonomi. Manusia bebas melakukan kegiatan ekonomi untuk meningkatkan taraf hidupnya. Etika dalam bisnis berfungsi untuk menolong pebisnis memecahkan permasalahan yang berkaitan dengan moral dalam praktek bisnis yang mereka hadapi. Etika bisnis Islam harus dipahami secara benar sehingga kemungkinan kehancuran bisnis akan kecil dan dengan etika yang benar tidak akan merasa dirugikan dan mungkin masyarakat dapat menerima manfaat yang banyak dari kegiatan jual dan beli yang dilakukan. ${ }^{14}$ Sedangkan sifat universal bisnis Rasulullah menurut Afzalurrahman ada empat macam yaitu:

a) Siddiq Yaitu tidak berdusta dan berkata jujur merupakan arti dari Siddiq yang harus dilakukan dalam melakukan berbagai macam transaksi bisnis.

b) Fatanah. Dapat diartikan cerdas, intelektual, kecerdikan. Pebisnis yang fatanah adalah pebisnis yang mempunyai kemauan berusaha mencari dan menemukan peluang-peluang bisnis yang baru, prospek

Kencana, 2006), 103.

13 Muhammad Djakfar, Etika Bisnis: Menangkap Spirit Ajaran Langit dan Pesan Moral Ajaran Bumi, (Jakarta: Penebar Plus, 2012), 30.

14 Dany Hidayat "Pencapaian Maslahah Melalui Etika Bisnis Islam Studi Kasus Restoran Mie Akhirat" Jurnal JESTT, Vol. 2, No. 11 (2015), 914. 
dan berwawasan masa depan, namun tidak mengabaikan prinsip kekinian.

c) Amanah berarti dapat dipercaya, kredibel dan bertanggung jawab.

d) Tabligh Yaitu komunikatif dan argumentatif. Istilah ini diterjemahkan dalam bahasa manajemen sebagai supel (mudah berkomunikasi), deskripsi tugas, delegasi wewenang, kerja tim, cepat tanggap, koordinasi, kendali dan supervise.

Jadi, dalam hal ini penulis menyimpulkan untuk memilih teori dari Muhammad Djakfar sebagai teori utama dengan menyatakan bahwa etika bisnis islam yaitu suatu norma-norma etika yang berbasis Al-Qur'an dan hadis yang harus dijadikan acuan oleh siapapun dalam aktivitas bisnisnya untuk mencapai tujuan yang maksimal, sedangkan teori yang lain sebagai pendukung teori utama.

\section{Prinsip-Prinsip Etika Bisnis Islam}

Menurut Muhammad Djakfar prinsip-prinsip etika bisnis dalam Islam, antara lain: ${ }^{15}$

Pertama, Jujur dalam takaran (quantity) dan berbisnis. Jujur dalam takaran ini sangat penting untuk diperhatikan terutama apabila menakar atau menimbang tanpa menguranginya karena kejujuran itu adalah salah satu kunci sukses seorang pelaku bisnis menurut Islam, apalagi di bisnis modern juga sangat menekankan prinsip ini. Seperti pada firman allah Swt sebagai berikut:

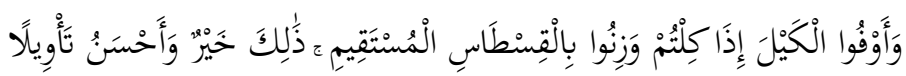

"Dan sempurnakanlah takaran apabila kamu menakar, dan timbanglah dengan neraca yang benar. Itulah yang lebih utama (bagimu) dan lebih baik akibatnya."(Al-Qur'an S. Al-Isro' : 35).

Kedua, Menjual barang yang baik mutunya (quality). Salah satu catat etis dalam perdagangan adalah tidak transparan dalam mutu, yang berarti mengabaikan tanggungjawab moral dalam dunia bisnis. Padahal yang diharapkan adalah sebuah keseimbangan antara memperoleh keuntungan dan memenuhi norma-norma dasar masyarakat baik berupa hukum, maupun etika.

Ketiga, Dilarang menggunakan sumpah (al-qosm). Seringkali ditemukan dalam kehidupan sehari-hari, terutama dikalangan para pedagang kelas bawah apa yang dikenal dengan obral sumpah. Mereka sering menggunakan sumpah untuk meyakinkan para pembeli bahwa

15 Muhammad Djakfar, Etika Bisnis......104.

$272 \mid$ JURNAL LISAN AL-HAL 
barang dagangannya berkualitas. Dalam hal ini seorang penjual diharapkan bersikap ramah dan bermurah hati kepada setiap pembeli. Dengan sikap tersebut berharap mendapatkan berkah dalam penjualan dan akan diminati oleh pembeli karena sebuah kebenaran itu datangnya dari Allah. Seperti firman Allah Swt:

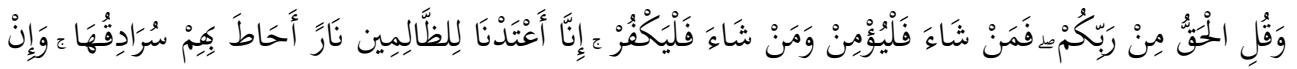

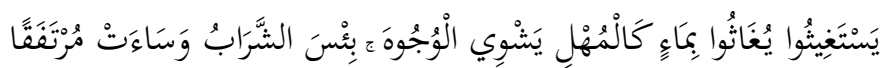

"Kebenaran itu datangnya dari Tuhanmu; maka barang siapa yang ingin (beriman) hendaklah ia beriman, dan barangsiapa yang ingin (kafir) biarlah ia kafir". Sesungguhnya Kami telah sediakan bagi orang orang zalim itu neraka, yang gejolaknya mengepung mereka. Dan jika mereka meminta minum, niscaya mereka akan diberi minum dengan air seperti besi yang mendidih yang menghanguskan muka. Itulah minuman yang paling buruk dan tempat istirahat yang paling jelek."(Al-Qur'an S. Al-Kahfi: 29).

Keempat, Longgar dan bermurah hati (tatsamuh dan taraahum). Dalam transaksi bisnis pasti ada sistem jual beli disini diharapkan penjual bersifat ramah dan bermurah hati kepada setiap pembeli.

Kelima, Membangun sifat tanggungjawab dalam bisnis artinya manusia harus bisa mempertanggungjawabkan keputusan yang mereka pilih tidak hanya di hadapan manusia tapi juga dihadapan allah Swt kelak di akhirat. Sebagaiman firman Allah Swt berikut ini:

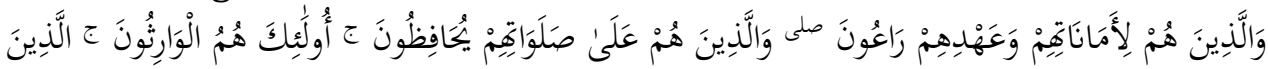

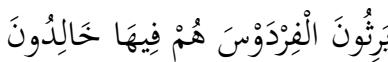

"dan orang-orang yang memelihara amanat-amanat dan janjinya, serta orang yang memelihara solatnya, mereka itulah orang-orang yang akan mewarisi, yang mewakili firdaus mereka akan kekal didalamnya."(Al-qur'an S. Al-Mukminun: 8-11).

Keenam, Tertib administrasi. Dalam perdangan wajar terjadi praktik pinjam meminjam, perlunya administrasi hutang piutang tersebut agar manusia terhindar dari kesalahan yang mungkin terjadi.

Ketujuh, Keseimbangan dalam berbisnis. Dalam suatu kehidupan membutuhkan keseimbangan dalam memenuhi kebutuhan manusia. Bukan hanya mementingkan urusan duniawi melainkan juga melakukan urusan akhirat. Untuk itu dalam islam mengajarkan untuk berbuat adil, baik adil terhadap hak orang lain, maupun hak lingkungan sosial, hak alam semesta dan sang pencipta.

Selain itu, etika bisnis Islami harus berdasarkan pada prinsipprinsip dasar yang berlandaskan Al-Qur'an dan Al-Hadis. Adapun prinsip

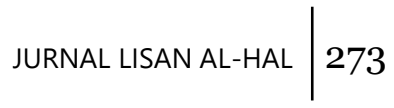


atau aksioma yang perlu diterapkan dalam bisnis Islam adalah sebagai berikut:

1) Kesatuan (Unity)

Prinsip ini dimaksudkan bahwa sumber utama etika Islam adalah kepercayaan total dan murni terhadap kesatuan (keesaan) Tuhan. Kenyataan ini secara khusus menunjukkan dimensi vertikal Islam yang menghubungkan institusi-institusi sosial yang terbatas dan tidak sempurna dengan Dzat yang sempurna dan tidak terbatas. Hubungan vertikal ini merupakan wujud penyerahan diri manusia secara penuh tanpa syarat di hadapan Tuhan, dengan menjadikan keinginan, ambisi serta perbuatannya tunduk pada titah-Nya: ${ }^{16}$

Dalam Al-Qur'an Allah Berfirman: AL-Iklas.1-5. Ketundukan manusia pada Tuhan telah membantu mereka merealisasikan potensi teomorfiknya, sekaligus membebaskannya dari perbudakan manusia. Dengan mengintegrasikan aspek religius dengan aspek kehidupan yang lain, seperti ekonomi, mendorong manusia ke dalam suatu keutuhan yang selaras, konsisten dalam dirinya dan selalu merasa diawasi oleh Tuhan, peran integrasi dalam konsep kesatuan menimbulkan rasa selalu merasa direkam oleh yang maha melihat segala aktivitas kehidupannya, termasuk dalam aktivitas berekonomi.

2) Kesetimbangan (Equilibrium)

Dalam beraktivitas di dunia kerja dan bisnis, Islam mengharuskan untuk berbuat adil. Pengertian adil dalam Islam diarahkan agar hak orang lain, hak lingkungan sosial, hak alam semesta dan hak Allah dan Rasulnya berlaku sebagai stakeholders dari perilaku adil seseorang. Semua hak-hak tersebut harus ditempatkan sebagaimana mestinya (sesuai aturan syariah). Tidak mengakomodir salah satu hak di atas, dapat menempatkan seseorang tersebut pada kezhaliman. Karenanya orang yang adil lebih dekat kepada ketakwaan. ${ }^{17}$

3) Kehendak bebas (Free Will)

Kehendak bebas merupakan kontribusi Islam yang paling orisinal dalam filsafat sosial tentang konsep manusia "bebas". Memang hanya Tuhan yang bebas, namun dalam batas-batas skema penciptaan-Nya manusia secara relatif mempunyai kebebasan. Manusia sebagai khalifah di muka bumi (sampai batas-batas tertentu) mempunyai kehendak bebas untuk mengarahkan kehidupannya pada tujuan pencapaian kesucian diri.

16 Syed Nawab Haider Naqvi, Menggagas Ilmu Ekonomi Islam terj. M. Saiful Anam dan Muhammad Ufuqul Mubin (Yogyakarta: Pustaka Pelajar, 2003), 37.

${ }^{17}$ Faisal Badroen, Etika Bisnis dalam Islam (Jakarta: Kencana, 2006), 91.

$274 \mid$ JURNAL LISAN AL-HAL 
Manusia dianugerahi kehendak bebas (free will) untuk membimbing kehidupannya sebagai khalifah. Berdasarkan aksioma kehendak bebas ini, dalam bisnis, manusia mempunyai kebebasan untuk membuat suatu perjanjian, termasuk menepati janji atau mengingkarinya. Seorang Muslim yang percaya pada kehendak Allah, akan memuliakan semua janji yang telah dibuatnya. Ia merupakan bagian kolektif dari masyarakat dan mengakui bahwa Allah meliputi kehidupan individual dan sosial. Dengan demikian, kebebasan kehendak berhubungan dengan kesatuan dan kesetimbangan. ${ }^{18}$

4) Tanggung Jawab (Resposibility)

Kebebasan tanpa batas adalah suatu hal yang mustahil dilakukan oleh manusia karena tidak menuntut adanya pertanggungjawaban dan akuntabilitas. Untuk memenuhi tuntutan keadilan dan kesatuan, manusia perlu mempertanggungjawabkan tindakannya. Secara logis aksioma ini berhubungan erat dengan aksioma kehendak bebas. Ia menetapkan batasan mengenai apa yang bebas dilakukan oleh manusia dengan bertanggung jawab atas semua yang dilakukannya. ${ }^{19}$

5) Kebenaran (Benevolence)

Kebenaran dalam konteks ini mengandung dua unsur, yaitu kebajikan dan kejujuran. Kebenaran adalah nilai kebenaran yang dianjurkan dan tidak bertentangan dengan ajaran Islam. Dalam konteks bisnis kebenaran dimaksudkan sebagai niat, sikap dan perilaku yang benar, yang meliputi proses akad (transaksi), proses mencari dan memperoleh komiditas, proses pengembangan maupun dalam proses upaya meraih atau menetapkan margin keuntungan (laba). ${ }^{20}$ Kebijakan adalah sikap ihsan, benevolence yang merupakan tindakan yang memberi keuntungan bagi orang lain. Dalam pandangan Islam sikap ini sangat dianjurkan.

Aplikasinya, menurut al-Ghazali terdapat tiga prinsip pengejawentahan kebijakan: pertama, memberi kelonggaran waktu kepada pihak terhutang untuk membayar hutangnya. Jika perlu mengurangi beban hutangnya. Kedua, menerima pengembalian barang yang telah dibeli. Ketiga, membayar hutang sebelum waktu penagihan tiba. Sedangkan kejujuran adalah sikap jujur dalam semua

${ }^{18}$ Fauroni, Etika Bisnis.........., 151-152

${ }^{19}$ Faisal Badroen, Etika Bisnis.........102.

${ }^{20}$ Muhammad dan Alimin, Etika \& Perlindungan Konsumen dalam Ekonomi Islam (Yogyakarta: BPFE, 2004), 299. 
proses bisnis yang dilakukan tanpa adanya penipuan sedikitpun. Sikap ini dalam khazanah Islam dapat dimaknai dengan amanah.

Dari sikap-sikap dan kesadaran tentang kesatuan, kesetimbangan, tanggung jawab di atas dengan otomatis melahirkan kebaikan-kebaikan kepada orang lain yang memberikan manfaat saling keuntungan yang bukan semata-mata keuntungan material tetapi juga keuntungan dan kepuasan spiritual. Selain itu melahirkan pula sikap saling pengertian, kesukarelaan dan persaudaraan secara otomatis. Persaudaraan, kemitraan antara pihak-pihak yang berkepentingan dalam bisnis yang saling menguntungkan, tanpa adanya kerugian dan penyesalan. ${ }^{21}$

Buku lainnya adalah karya Musa Asy'arie yang berjudul Islam: Etika dan Konspirasi Bisnis. Dalam buku ini dijelaskan bahwa setiap kegiatan bisnis dalam Islam selalu memiliki etika yang harus dipedomani dan dijadikan dasar bisnis tersebut. Etika bisnis itu antara lain: ${ }^{22}$

1) Jujur dan Amanah. Jujur adalah kesamaan antara berita yang disampaikan dengan fakta atau fenomena yang ada. Sebelum menjadi rasul Allah, Nabi Muhammad adalah seorang guru Entrepreneur sukses dan profesional yang selalu mengutamakan kejujuran dalam hubungan transaksinya dengan semua pelanggannya. ${ }^{23}$ Syaikh Al-Qardhawi berpendapat bahwa jujur adalah nilai terpenting dalam transaksi sebuah bisnis Dalam kegiatan bisnis harus ada kejujuran karena tanpa kejujuran bisnis akan hancur. Kejujuran adalah menjaga amanah atau kepercayaan semua hal terkait dengan bisnis atau stakeholders. Oleh karena itu untuk menjaga agar amanah dapat dijalankan dengan baik perlu ada catatan yang jelas terhadap apa yang sudah disepakati bersama dalam perjanjian bisnis. Disamping itu perlu adanya keterbukaan antara pelaku bisnis jangan sampai ada dusta dibelakang hari yang mengakibatkan kerjasama bisnis itu mengalami krisis kepercayaan yang dapat membuatnya bangkrut.

2) Tidak Merugikan Orang Lain. Bisnis dalam Islam memandang orang lain sebagai subyek, bukan sematamata sebagai obyek bisnis. Sebagai subyek bisnis, maka orang lain adalah pembeli atau pemakai jasa atau barang yang kita tawarkan, tetapi disaat yang sama orang lain itu

\footnotetext{
${ }^{21}$ Muhammad dan Alimin, Etika \& Perlindungan Konsumen dalam Ekonomi Islam (Yogyakarta: BPFE, 2004), 299.

22 Musa Asy'arie,Islam: Etika \& Konspirasi Bisnis,(Yogyakarta: Lembaga Studi Filsafat Islam(LESFI), 2016 ), 56.

${ }^{23}$ Akhmad Nur Zaroni, Bisnis Dalam Perspektif Islam (Telaah Aspek Keagamaan dalam Kehidupan Ekonomi), Mazahib Vol. IV, No. 2, Desember 2007, 182.
}

$276 \mid$ JURNAL LISAN AL-HAL 
mempunyai posisi dan kedudukan yang sama dengan kita, sebagai sesama manusia hamba Allah SWT yang tidak boleh dizalimi, disakiti dan dirugikan. Pelaku bisnis yang merugikan orang lain pada akhirnya akan merugikan dirinya sendiri. Karena apa yang dilakukan kepada orang lain itu akan terjadi juga pada dirinya.Orang lain dalam bisnis harus dilihat sebagai mitra yang tidak boleh dirugikan.

3) Keseimbangan Pembagian Keuntungan. Keseimbangan dalam bisnis dapat diartikan keseimbangan dalam mendapatkan dan membagi keuntungan, keseimbangan antara hak dan tanggungjawab. Keseimbangan dalam bisnis perlu dijaga, agar perkembangannya dapat dikendalikan, jangan sampai melewati batas-batas moral yang sudah ditetapkan sejak awalnya. Keseimbangan adalah dasar kehidupan yang sejak awal diciptakan Tuhan dalam kehidupan manusia dan alam semesta. Tanpa keseimbangan suatu bisnis akan runtuh.

4) Keadilan Dalam Bisnis. Keadilan adalah prinsip umum etika dalam Islam, baik dalam kaitan hukum,politik, ekonomi, budaya, sosial, maupun keagamaan. Keadilan adalah jiwa kehidupan masyarakat. Jikalau dalam kehidupan masyarakat tidak terdapat keadilan maka penindasan satu sama lain akan berlangsung dan menyeret masyarakat dalam konflik kekerasan yang akhirnya akan merusak kehidupan masyarakat secara keseluruhan.

5) Memandang positif pesaing bisnis. Pelaku bisnis harus memandang adanya pesaing bukan suatu ancaman baginya, tetapi menjadi tantangan untuk lebih maju lagi. Dari pesaing kita tahu banyak kelemahan/kekurangan yang ada pada diri kita yang harus dibenahi. Disamping itu dengan adanya pesaing menjadi keuntungan bagi konsumen karena adanya pilihan baginya untuk mencari yang lebih baik. Inilah prinsip fastabiqul khairat bersaing dalam kebaikan dan dengan menempuh cara-cara yang baik, sebagai bagian dari usaha untuk memajukan usaha bisnisnya yang akan membuatnya semakin kuat. Adanya pesaing adalah realitas dalam kehidupan manusia yang harus diterima secara positif sebagai cara untuk bertindak rasional dan konstruktif untuk membuat bisnisnya lebih maju lagi. Dalam berbisnis tidak boleh mematikan pesaing bisnis karena akan melemahkan bisnis kita sendiri. ${ }^{24}$

Buku Veithzal Rivai yang lainnya berjudul Islamic Business and Economic Ethics. Didalam buku ini dijelaskan bahwa Rasulullah saw.

24 Musa Asy'arie, Islam: Etika \& Konspirasi Bisnis, (Yogyakarta: Lembaga Studi Filsafat Islam (LESFI), 2016), 57-82. 
Sangat banyak memberikan petunjuk mengenai etika bisnis, berikut ini adalah uraiannya:

1) Kejujuran adalah prinsip esensial dalam bisnis. Kejujuran merupakan syarat fundamental dalam kegiatan bisnis. Rasulullah saw. sendiri selalu bersikap jujur dalam berbisnis.

2) Kesadaran tentang signifikan sosial kegiatan bisnis. Pelaku bisnis menurut Islam, tidak hanya mengejar keuntungan sebanyakbanyaknya, sebagaimana yang diajarkan Bapak ekonomi kapitalis, Adam Smith, tetapi juga berorientasi kepada sikap ta'awun (menolong orang lain) sebagai implikasi sosial kegiatan bisnis.

3) Tidak melakukan sumpah palsu. Dalam sebuah hadits riwayat Bukhari, Nabi bersabda "Dengan melakukan sumpah palsu, barang-barang memang terjual, tetapi hasilnya tidak berkah". Praktik sumpah palsu dalam kegiatan bisnis saat ini sering dilakukan, karena dapat meyakinkan pembeli, dan pada gilirannya meningkatkan daya beli atau pemasaran, namun harus disadari bahwa meskipun keuntungan yang diperoleh berlimpah tetapi hasilnya tidak berkah.

4) Ramah-tamah. Nabi Muhammad saw, mengatakan "Allah merahmati seseorang yang ramah dan toleran dalam berbisnis" (HR. Bukhari dan Tarmizi).

5) Tidak boleh berpura-pura menawar dengan harga tinggi, agar orang lain tertarik membeli dengan harga tersebut.

6) Tidak boleh menjelekkan bisnis orang lain, agar orang membeli kepadanya.

7) Tidak melakukan ihtikar. Ihtikar ialah menumpuk dan menyimpan barang dalam masa tertentu, dengan tujuan agar harganya suatu saat menjadi naik dan keuntungan besar pun diperoleh.

8) Takaran, ukuran dan timbangan yang benar dan tepat harus benarbenar diutamakan. ${ }^{25}$

Jadi dapat disimpulkan bahwa penulis mengambil teori utama terkait prinsip etika bisnis islam dari muhammad djakfar karena teori yang telah diterapkan oleh beliau menjelaskan prinsip-prinsip etika bisnis yang menggunakan dasar-dasar hukum dari Al-Qur'an untuk memperkuat teorinya. Sedangkan untuk teori dari beberapa ilmuan hanya sebagai teori pendukung karena terdapat perbedaan penerapan etika bisnis islam yang perlu diterapkan dan digunakan oleh penulis untuk menjadi sebuah landasan dalam menyelesaikan permasalahan.

25 Veithzal Rivai, Amiur Nuruddin, dan Faisar Ananda Arfa, Islamic Business and Economic Ethics (Jakarta: Bumi Aksara, 2012), 39-41.

$278 \mid$ JURNAL LISAN AL-HAL 


\section{Tujuan Bisnis Dalam Islam}

Bisnis dalam islam bertujuan untuk mencapai empat hal utama yaitu antara lain yang pertama target hasil: profit-materi dan benefit-non materi, yang kedua pertumbuhan, ketiga keberlangsungan, keempat keberkahan: Target hasil: profit-materi dan benefit-non materi, artinya bahwa bisnis tidak hanya untuk mencari profit (nilai materi) setinggitingginya, tetapi juga harus dapat memperoleh dan memberikan keuntungan non materi kepada internal organisasi perusahaan dan eksternal, seperti terciptanya suasana persaudaraan, kepedulian sosial dan sebagainya. Keuntungan yang dimaksud tidaklah semata memberikan manfaat kebendaan, tetapi juga dapat bersifat non materi. Islam memandang bahwa tujuan suatu amal perbuatan tidak hanya beroriantasi pada qimah madiyah. Pertumbuhan, jika profit materi dan profit non materi telah diraih, perusahaan harus berupaya menjaga pertumbuhan agar selalu meningkat. Upaya peningkatan ini juga harus selalu dalam koridor syariah, bukan menghalalkan segala cara. Keberlangsungan, target yang telah dicapai tidak dengan pertumbuhan setiap tahunnya harus dijaga keberlangsungannya agar perusahaan dapat exsis dalam kurun waktu yang lama. Keberkahan, senua tujuan yang telah tercapai tidak berarti apa-apa jika tidak ada keberkahan didalamnya. Maka bisnis islam menempatkan berkah sebagai tujuan inti, karena merupakan bentuk dari diterimannya segala aktivitas manusia. Keberkahan ini menjadi bukti bahwa bisnis yang dilakukan pengusaha muslim telah mendapatkan ridha dari allah Swt. Dan bernilai ibadah.

\section{Kendala-kendala dalam Pelaksanaan Etika Bisnis Syariah}

Dalam pelaksanaan prinsip-prinsip etika bisnis syariah di suatu usaha masih memiliki beberapa masalah dan kendala. Keraf menyebut beberapa kendala tersebut yaitu:

a. Standar moral para pelaku bisnis yang masih lemah. Banyak di antara pelaku bisnis yang lebih suka menempuh jalan pintas, bahkan menghalalkan segala cara untuk memperoleh keuntungan dengan mengabaikan etika bisnis, seperti memalsukan campuran, timbangan, ukuran, menjual barang yang kadaluwarsa, dan memanipulasi laporan keuangan.

b. Tidak memiliki kesadaran diri dalam menjalankan suatu peraturan yang berlaku. Kesadaran dalam diri seseorang sangat diperlukan dalam penerapan suatu moral atau etika dalam berbisnis. Banyak orang yang mengetahui aturan dan etika yang berlaku dalam suatu 
pengelolaan bisnis tetapi mereka tidak menerapkannya karena kurang adanya kesadaran dalam masing-masing individu.

c. Lemahnya penegakan hukuman. Banyaknya orang yang sudah melanggar dan bersalah dalam perilaku moral dalam berbisnis yang dibiarkan dan tetap memangku jabatannya di sebuah bisnis tersebut. Kondisi ini mempersulit upaya untuk memotivasi perilaku bisnis islam menegakkan norma-norma etika.

d. Tidak adanya sebuah kepercayaan. Dalam sebuah bisnis diperlukan sebuah kepercayaan dalam proses pembangunan dan pengembangan suatu usaha, banyak seorang konsumen yang kurang percaya dalam proses dan hasil produk yang dibuat oleh produsen. Apalagi suatu produk yang baru dikeluarakan.

e. Hutang piutang dalam sebuah transaksi. Peristiwa ini selalu menjadi sebuah hambatan dalam pengelolaan bisnis baik nanti dalam segi produksi maupun dalam pembuatan laporan administrasi pada akhir tahun.

\section{Metodologi Penelitian}

Metode penelitian merupakan prosedur dan cara melakukan verifikasi data yang diperlukan untuk memecahkan dan menjawab masalah penelitian. Dengan kata lain, metode penelitian akan memberikan petunjuk bagaimana penelitian itu dilaksanakan. ${ }^{26}$ Penelitian yang peneliti lakukan tergolong sebagai penelitian lapangan yakni penelitian yang langsung dilakukan pada responden. Oleh karena itu, obyek penelitiannya adalah berupa obyek lapangan yang sekiranya mampu memberikan informasi tentang kajian penelitian. ${ }^{27}$ Dalam hal ini peneliti menjadikan HCG (Hikma Collection Group) Miftahul Hikmah Karang sebagai obyek penelitian yang difokuskan pada implementasi etika bisnis syari'ah, sehingga dapat mengetahui etika bisnis yang digunakan pada pengelolaan HCG (Hikma Collection Group). Jenis penelitian dalam penyusunan karya ilmiah ini merupakan jenis penelitian kualitatif. Penelitian kualitatif merupakan prosedur penelitian yang menghasilkan data deskriptif berupa kata-kata tertulis atau lisan dari orang-orang dan pelaku yang diamati. ${ }^{28}$

${ }^{26}$ Nana Sudjana dan Ibrahim, Penelitian dan Penelitian Pendidikan (Bandung: Sinar Baru, 1989), 16.

${ }^{27}$ M. Iqbal Hasan, Pokok-Pokok Materi Metode Penelitian dan Aplikasinya (Jakarta: Ghalia Indonesia, 2002), 11.

28 Lexy J. Moleong, Metodologi Penelitian Kualitatif (Bandung: PT. Remaja Rosdakarya, 2005), Cetakan. 1, 4.

$280 \mid$ JURNAL LISAN AL-HAL 
Pendekatan yang dipakai dalam penelitian ini adalah pendekatan kualitatif. Pendekatan kualitatif pada hakikatnya ialah mengamati orang dalam hidupnya, beriteraksi dengan mereka berusaha memahami Bahasa dan tafsiran mereka tentang dunia sekitarnya. ${ }^{29}$

Dengan kata lain, pendekatan kualitatif adalah prosedur penelitian yang bersumber dari buku-buku, terhadap suatu masalah yang menghasilkan data diskriptif yang berupa kata-kata tertulis bukan berupa kuantitatif atau hitungan. ${ }^{30}$ Penelitian ini dilaksanakan di salah satu konveksi yang berdiri di bawah pimpinan Pondok Pesantren Miftahul Hikmah Karang bernama HCG (Hikma Collection Group). Lokasi tempat penelitian yang digunakan sipenulis untuk memperolah informasi atau data-data yang dibutuhkan yaitu, Jl. Pondok Pesantren Miftahul Hikmah Karang Sukorejo, Parengan, Tuban. Teknik analisis data merupakan proses mencari dan menata data dari hasil wawancara, dan dokumentasi secara sistematis untuk meningkatkan pemahaman peneliti tentang kasus yang diteliti dan menyajikannya sebagai temuan bagi yang lain. ${ }^{31}$

\section{Hasil Dan Diskusi}

1. Implementasi etika bisnis Islam dalam pengelolaan HCG (Hikma Collection Group) di Miftahul Hikmah Parengan Tuban.

Dari hasil penelitian dapat di ketahui bahwa penerapan etika bisnis Islam dalam pengelolaan HCG (Hikma Collection Group) menggunakan delapan prinsip etika bisnis Islam yaitu kejujuran, menjual barang yang baik mutunya, tidak mengobral sumpah, bertanggung jawab dalam bisnis, bermurah hati, keseimbang dalam berbisnis, tertib administrasi dan menempati janji sesuai dengan target yang diberikan konsumen. Sedangkan dari hasil opservasi peneliti hanya menemukan empat etika bisnis yang telah diterapkan yaitu bermurah hati dengan semua konsumen, menjual barang yang baik mutunya, tertib dalam beradministrasi serta selalu menempati janji sesuai dengan target yang diberikan konsumen. Dari beberapa data yang telah dikumpulkan melalui wawancara dan observasi dapat dibuktikan dengan prinsip bermurah hati kepada konsumen dan sesama pegawai, berperilaku seimbang dalam berbisnis dengan tetap mematuhi peraturan pondok pesantren yang mewajibkan jama'ah jadi pegawai tidak hanya mencukupi urusan dunia

${ }^{29}$ Nasution, Metode Penelitian Naturalistik-Kualitatif (Bandung: Tarsito, 2002), 5.

30 Margono, Metodologi Penelitian (Jakarta: Ghalia Indonesia, 1998), 111-112.

31 S. Margono, Metodologi Penelitian (Jakarta: PT. Rineka Cipta, 2000), Cetakan 2, 165. 
saja tetapi juga kebutuhan akiratnya, prinsip selanjutnya terdapat tertib dalam beradministrasi hal ini bisa dilihat dari hasil laporan keuangan pertahunnya, serta memiliki prinsip menempati janji kepada konsumen yang memberikan target dalam penyelesain pesanan.

HCG (Hikma Collection Group) yang berada di naungan Pondok Pesantren Miftahul Hikmah memiliki karyawan yang semuanya dari santri, Sikap etika santri dalam berbisnis itu diharapkan akan melahirkan kesadaran diri terkait etika berbisnis yang sesuai dengan ajaran Islam melalui standart Standard Operating Procedure (SOP) mengutamakan prinsip kejujuran dalam pengelolaan bahan dan hasil produk bukan hanya itu jujur dalam menjual barang yang baik dan bermutu sesuai dengan penetapan harga jualnya serta selalu bersikap ramah kepada konsumen. Hal tersebut berdasarkan hasil wawancara dari Nur khamim selaku penanggung jawab bagian sablon yang menyatakan bahwa: ${ }^{32}$

"Dalam penerapan etika bisnis Islam yang telah diterapkan dari awal pendirian HCG (Hikma Collection Group) sampai sekarang yaitu sebuah kejujuran dari semua karyawan dan pengelola terhadap pembuatan suatu produk yang berkualitas, karena dengan adanya sifat jujur dan tanggungjawab dalam mengambil keputusan yang diterapkan dalam masing-masing pegawai akan memberikan dampak yang baik terhadap perkembangan suatu bisnis ini. Bukan hanya itu hal yang diterapkan dalam pelaksanakan usaha harus memiliki sifat bermurah hati dan longgar dalam suatu transaksi jual beli dan tertib dalam beradministrasi artinya selalu memberikan rincian dalam laporan akhir setiap tahunnya."

Hasil wawancara tersebut dapat disimpulkan bahwa etika bisnis Islam yang sudah diterapkan di HCG (Hikma Collection Group) adalah prinsip kejujuran masing-masing pegawai terhadap pengelolaan produkproduk yang dihasilkannya seperti memproduksi dengan bahan yang halal dan berkualitas sesuai keinginan konsumen, memiliki sifat murah hati terhadap konsumen dengan tidak mengharap imbalan lebih dari kosumen dan membantu orang lain, dan tanggungjawab Baik seperti ketika ada komplain dari konsumen itu nanti dari penjahitan maupun penyablonannya dan adanya tertib dalam administrasi pengelolaan bisnisnya. Dalam adanya administrasi yang selalu dibuat di akhir tahun serta bentuk laporan keuangan yang mudah dimengerti serta jujur dan

32 Hasil Wawancara Dengan Khamim Selaku Pegawai HCG (Hikma Collection Group) Dan Santri Pondok Pesantren Miftahul Hikmah, Tanggal 18 Maret 2020, Pukul 13.00-13.30.

$282 \mid$ JURNAL LISAN AL-HAL 
tidak berpihak pada kepentingan manapun. Dalam penyusunan laporan keuangan membutuhkan ketelitian serta penyusunan yang tepat seperti merekap semua pengeluaran dan pemasukan setiap bulannya.

Sifat murah hati terhadap konsumen ini telah terbukti dari hasil observasi yaitu adanya keramahan dalam mejual produk kepada konsumen melalui senyum, salam dan prilaku yang sopan terhadap konsumen ketika menawarkan barang. Selain itu dalam tertib administrasi juga dibuktikan dari hasil dokumentasi berupa buku laporan keuangan di HCG (Hikma Collection Group). Laporan keuangan ini dibuat setiap dalam satu tahun sekali, Sebuah implementasi Etika Bisnis Islam bukan hanya terkait tentang etika seorang pegawai saja tetapi tentang usaha yang harus memiliki komitmen dalam pelaksanaan etika bisnis Islam tersebut. Berikut hasil wawancara dari Sutikno selaku ketua usaha HCG (Hikma Collection Group):33

"Dalam penerapan Etika Bisnis Islam di HCG (Hikma Collection Group) ini akan berpengaruh dalam perkembangan bisnis tersebut terutama dalam proses pengembangan di zaman modern ini harus memiliki prinsip menempati janji dalam memenuhi keinginan seorang konsumen karena dengan adanya penempatan janji tersebut akan membentuk kepercayaan pelanggan yang nantinya akan berdampak terhadap minat konsumen lainnya. Bahkan bisa jadi pelanggan tersebut akan menjadi pelanggan tetap di bisnis $H C G$ (Hikma Collection Group) ini. Hal ini bisa dibuktikan dari banyaknya pelanggan dari luar kota yang akhir-akhir ini semakin banyak serta bukan hanya itu sekarang terdapat konsumen dari luar provinsi. Prinsip ini saya terapkan disini karena banyaknya bisnis-bisnis konveksi pada saat ini sering menghianati janji setiap konsumen meminta tarjet penyelesaiannya. Untuk itu hal ini menjadi nilai plus di bisnis HCG (Hikma Collection Group) ini."

Dari keterangan di atas dapat disimpulkan bahwa bukan hanya prinsip kejujuran yang sudah diterapkan dalam pengelolaan HCG (Hikma Collection Group) tetapi prinsip penempatan janji yang telah diterapkan dari berdirinya HCG (Hikma Collection Group) ini sangat berpengaruh terhadap kepercayaan pelanggan, yang nantinya akan berdampak peminatan untuk membeli produk-produk yang kita hasilkan. Hal ini juga ditemukan dari hasil opservasi peneliti yaitu ketika konsumen ingin membeli barang jahitan dan harus selesai sesuai dengan target, kemudian

33 Hasil Wawancara Dengan Sutikno Selaku Ketua HCG (Hikma Collection Group), Tanggal 18 Mater 2020, Pukul 10.30-11.00. 
dari pihak pegawai memilih untuk menolaknya ketika tidak sanggup menyelesaikan pesanan barang tersebut. prinsip tersebut juga didukung hasil opservasi bahwa penerapan prinsip etika menempati janji ini telah dibuktikan dengan adanya penolakan kepada konsumen ketika dari pihak HCG (Hikma Collection Group) memang tidak sanggup menyelesaikan sesuai dengan target yang telah diinginkan konsumen tersebut. Terkait implementasi Etika Bisnis Islam yang diterapkan di HCG (Hikma Collection Group) yang sesuai ajaran Islam serta tanpa melanggar peraturan pondok pesantren, berikut hasil wawancara kepada K. Miftahul Asror selaku ketua yayasan Miftahul Hikmah Parengan Tuban: ${ }^{34}$

" membahas terkait etika bisnis Islam sebenarnya etika santri dalam bisnis itu diharapkan akan melahirkan sikap menahan diri memanfaatkan harta untuk kepentingan produktifitas duniawi dan ukhrowi. Etika bisnis santri mendorong para santri pelaku bisnis untuk mengubah harta bukan saja aset ilahiyah yang mempunyai nilai ekonomis, tetapi juga sebagai aset sosial dan mempunyai tanggung jawab pengawasan aktif terhadap pemanfaatan harta dalam masyarakat, dimana mekanisme keseimbangan dalam aktivitas sehari-hari dengan selalu mengikuti peraturan dan kegiatan yang terdapat didalam pesantren. bukan hanya itu prinsip yang perlu diterapkan juga yaitu tidak mengobral sumpah ketika menawarkan barang kepada konsumen, artinya harus apa adanya sesuai dengan yang kita produksi ".

Berdasarkan hasil wawancara di atas dapat disimpulkan bahwa penerepan etika bisnis Islam bisa berjalan dengan selalu hidup seimbang artinya bukan hanya urusan duniawai saja tetapi juga menjalankan ibadah untuk memenuhi kebutuhan ukrowi manusia. Tidak menggunakan sumpah dalam proses transaksi, dan menempati janji menjadi sikap yang diterapkan di HCG (Hikma Collection Group) ini. Hal ini juga sama seperti yang dikatakan oleh sulainah selaku penasehat di HCG (Hikma Collection Group) bahwa: ${ }^{35}$

" sebenarya dalam pesantren telah di pelajari etika dalam berbisnis yaitu didalam kitab-kitab muamalah seperti di dalam kitab iqya' karangan dari Imam Ghozali, bahwa harus melakukan adanya keseimbangan dalam bermuamalah serta harus memiliki rasa

34 Hasil Wawancara Kepada Pengasuh Dan Pendiri Pondok Pesantren Miftahul Hikmah, Tanggal 18 Maret 2020, Pukul 13.00-13.30.

35 Hasil Wawancara Dengan Sulainah Selaku Penasehat HCG (Hikma Collection Group), Tanggal 19 Maret 2020, Pukul 08.00-09.00.

$284 \mid$ JURNAL LISAN AL-HAL 
tanggungjawab terhadap bisnis yang telah dijalankan, yang pasti bisnis yang bebas riba dan selalu menempati janji terhadap konsumen"

Terdapat beberapa pendapat dari beberapa konsumen terkait penerapan etika bisnis yang telah diterapkan di HCG (Hikma Collection Group) ini, seperti yang disampaikan oleh Azizah selaku konsumen dari pondok pesantren Al Hikmah Tuban: ${ }^{36}$

" Etika dalam berbisnis sesuai dengan ajaran Islam artinya selalu bersikap bermurah hati dan selalu menempati janji sesuai dengan waktu yang saya minta. Pegawainya juga ramah-ramah serta baik terhadap konsumen yang prekonomiannya dibawah rata-rata, dan mereka juga sering memberikan Gratis ongkir ketika kita membeli Kaos santri"

Menurut Zainal selaku pelanggan kaos olahraga di HCG (Hikma Collection Group), Bahwa: ${ }^{37}$

"Etika bisnis Islam yang telah diterapkan selalu bersikap jujur dalam pengelolaan produk yang akan dihasilakn serta menentukan harga barang sesuai dengan mutu barang yang dihasilkan dan mereka selalu menolak jika memang tidak sanggup meyelesaikan pesanan sesuai dengan keinginan konsumen. biasanya jika di tempat konveksi lain pasti menyanggupi tapi nanti akhirnya konsumen kecewa karena tidak bisa menyelesaikan sesuai dengan keinginanya".

Dari hasil wawancara dengan beberapa konsumen dapat disimpulkan bahwa prinsip utama yang digunakan di HCG (Hikma Collection Group) yaitu dengan menempati janji artinya menyelesaikan pesanan konsumen sesuai dengan ketentuan waktu yang telah disepakati di awal transaksi. Serta penerapan sifat jujur dan bermurah hati atau ramah kepada konsumen. Derdasarkan hasil pengumpulan data yang dilakukan peneliti melalui hasil wawancara, hasil observasi dan dokumentasi dapat digambarkan dalam sebuah tabel berikut.

\section{Faktor Pendukung Dalam Penerapan Bisnis Islam Dalam Pengelolaan HCG (Hikma Collection Group).}

Dalam penerapan Etika Bisnis Islam dalam sebuah bisnis terdapat faktor yang mempengaruhinya. Begitu juga di HCG (Hikma Collection

${ }^{36}$ Hasil Wawancara Dengan Azizah Selaku Konsumen Di HCG (Hikma Collection Group), Tanggal 20 Maret 2020, Pukul 10.30-11.00.

37 Hasil Wawancara Dengan Zainal Selaku Konsumen Di HCG (Hikma Collection Group), Tanggal 20 Maret 2020, Pukul 13.00-13.30. 
Group) ini memiliki faktor pendukung dalam penerapan Etika Bisnis Islam. Dari hasil wawancara terdapat tiga faktor pendukung yaitu faktor lingkungan, faktor individu, dan faktor budaya lingkungan. Sedangkan dari hasil observasi terdapat dua faktor pendukung yaitu faktor lingkungan dan budaya perusahaan. Hasil wawancara terkait faktor pendukung implementasi etika bisnis Islam yang di paparkan oleh Sutikno selaku ketua HCG (Hikma Collection Group): ${ }^{38}$

"faktor pendukung penerapan etika bisnis Islam di HCG (Hikma Collection Group) ini didukung dari segi lingkungan, artinya bisnis yang berada didalam pondok pesantren mempermudah mereka untuk membudayakan etika bisnis Islam dengan baik, serta pengalaman dan pemahaman terkait ilmu agama Islam sudah tidak bisa diragukan lagi, karena setiap hari selalu mendapatkan ilmu-ilmu agama serta nasehat dari para pengurus pondok pesantren dan pemantauan dari pengasuh Pondok Pesantren Miftahul Hikmah ini."

Berdasarkan hasil wawancara di atas dapat disimpulkan bahwa faktor yang bisa mempengaruhi penerapan etika bisnis Islam di $H C G$ (Hikma Collection Group) yaitu faktor lingkungan yang berada didalam pondok pesantren akan menumbuhkan moral dan etika seorang muslim, bukan hanya itu di lingkungan pondok pesantren akan menjunjung tinggi kode etik dalam berbisnis. Faktor tersebut juga terbukti dari hasil opservasi yaitu dengan adanya kegiatan-kegiatan religius di pondok pesantren.

Penerapan etika bisnis dapat berjalan dengan baik jika memiliki kesadaran diri pada masing-masing karyawan karena yang dapat mengendalikan perilaku manusia itu adalah diri sendiri. ${ }^{39}$ seperti pendapat dari K. Miftahul Asror selaku pengasuh dan pendiri pondok pesantren Miftahul Hikmah bahwa:

"penerapan etika bisnis Islam bisa dilakukan dengan mudah ketika adanya faktor individu artinya memiliki kesadaran akan pentingnya etika bisnis Islam dalam sebuah pongelolaan bisnis. Meskipun nanti terdapat faktor pendukung dari kesadaran diri itu seperti pengaruh teman dan pengalaman hidup seseorang. Dan faktor lain juga bisa muncul ketika kondisi atau situasi yang bisa mempengaruhi

38 Hasil Wawancara Dengan Sutikno Selaku Ketua HCG (Hikma Collection Group), Tanggal 18 Maret 2020, Pukul 11.00-11.30.

39 Hasil Wawancara Dengan Pengasuh Pondok Pesantren Miftahul Hikmah, Tanggal 18 Maret 2020, Pukul 13.30-13.45.

$286 \mid$ JURNAL LISAN AL-HAL 
keyakinan terhadap diri sendiri, hal itu akan memberikan kontribusi yang cukup besar terhadap pembentukan perilaku etika seseorang."

Berdasarkan hasil wawancara tersebut dapat disimpulkan bahwa bukan hanya faktor lingkungan yang mempengaruhi penerapan etika bisnis Islam dalam pengelolaan HCG (Hikma Collection Group) tetapi yang sangat berpengaruh lebih banyak itu faktor individu artinya adanya kesadaran diri terhadap pentingnya moral atau etika dalam berbisnis, karena dengan adanya kesadaran diri akan memudahkan seseorang untuk mengontrol perilakunya masing-masing.

Terdapat salah satu pendapat dari para konsumen terkait faktor pendukung penerapan etika bisnis Islam, seperti Nuriyah selaku ketua organisasi kopri yang memesan kaos komunitas:40

" sebenarnya penerapan etika bisnis Islam dalam HCG (Hikma Collection Group) memiliki faktor pendukung yaitu budaya perusahaan yang telah dibuat sejak terbentuknya bisnis tersebut, karena nilai, norma dan pola tingkah laku yang menjadi karakteristik suatu perusahaan tersebut akan memiliki dimensi etika yang didorong dengan dengan kebijakan-kebijakan formal dan kebiasaankebiasaan sehari-hari yang telah berkembang dalam usaha tersebut. Aturan-aturan yang terdapat dalam HCG (Hikma Collection Group) ini juga memiliki etoka dan moral yang sesuai dengan prinsip etika bisnis Islam."

Berdasarkan hasil wawancara dan observasi di atas dapat disimpulkan bahwa bukan hanya faktor lingkungan dan individu yang mendorong penerapan etika bisnis Islam di HCG (Hikma Collection Group) tetapi juga faktor kebudayaan dalam suatu perusahaan dapat mempengaruhi penerapan etika, moral dan tingkah laku yang sesuai dengan prinsip-prinsip etika bisnis Islam, Yang dibuktikan dengan adanya sangsi yang diberikan kepada pegawai yang melanggar peraturan yang dibuat.

\section{Faktor Hambatan dan Kendala dalam Penerapan Etika Bisnis Islam dalam Pengelolaan HCG (Hikma Collection Group).}

Dalam melakukan penerapan etika bisnis Islam dalam pengelolaan HCG (Hikma Collection Group) tentunya terdapat beberapa hambatan dan kendala yang harus di hadapi di HCG (Hikma Collection Group) yaitu kurang adanya kepercayaan konsumen, tidak memiliki kesadaran diri

40 Hasil Wawancara Kepada Nuriah Selaku Konsumen Di HCG (Hikma Collection Group), Tanggal 20 Maret 2020, Pukul 15.00-15.30. 
sendiri, dan adanya hutang konsumen yang mengakibatkan kesulitan dalam pemutaran produksi. seperti yang di paparkan oleh sutekno selaku ketua HCG (Hikma Collection Group) sebagai berikut: ${ }^{41}$

"hambatan yang sering dialami itu sebenarnya sering dari anggota pegawai HCG (Hikma Collection Group) sendiri, karena tidak adanya kesadaran diri dalam menerapkan etika bisnis, meskipun seperti itu setiap hari selalu diamati dan selalu diberikan pengarahan hal ini karena semua pegawai dari kalangan santri yang masih Smk/MA, remaja yang masih seusia tersebut pemikirannya masih selalu ingin bebas bermain, makanya selalu ada nasehat yang selalu diberikan agar mereka sadar akan pentingnya etika bisnis Islam yang harus diterapkan serta kurang adanya penegakan hukuman atau sanksi ketika adanya pelanggaran dalam etika bisnis Islam yang tidak berjalan."

Dari hasil wawancara di atas dapat disimpulkan bahwa perilaku penerapan etika bisnis Islam di HCG (Hikma Collection Group) memiliki hambatan dan kendala yaitu tidak adanya kesadaran diri dari masingmasing anggota atas pentingnya penerapan etika bisnis Islam dalam suatu bisnis dan lemahnya hukuman atau sanksi ketika adanya pelanggaran dalam penerapan etika bisnis Islam, hal ini dapat di buktikan dari hasil opservasi bahwa masih adanya pegawai selalu diberi pengarahan dan nasehat dari ketua dan pengasuh Pondok Pesantren. Adapun hambatan yang ada dan harus dihadapi dalam pemasaran produk serta melayani pelanggan yang sering terjadi seperti yang di paparkan oleh ibu rita selaku pegawai HCG (Hikma Collection Group) sebagai berikut:

"kendala yang sering terjadi dalam pemasaran produk di $H C G$ (Hikma Collection Group) ini ketika ada konsumen yang sudah memilih-milih desain untuk disablon tiba-tiba dalam proses pembuatan terus mereka membatalkan dengan alasan takut hasilnya tidak bisa seperti yang ada digambar, dan ketika saya selaku penjual memberikan pemahan yang sesuai dengan keadaan, mereka malah menganggap bahwa semua penjual pasti akan berkata seperti itu agar dibeli barang dagangannya."

Hasil wawancara diatas dapat disimpulkan dan diketahui bahwa hambatan dan kendala dalam melakukan penbentukan etika bisnis Islam dalam pemasaran produk seperti itu ternyata tidak mudah karena mendapatkan sebuah kepercayaan dari konsumen itu butuh proses dan menghadapi karakter konsumen itu juga tidak mudah. Hambatan lain juga

${ }^{41}$ Hasil Wawancara Dengan sutekno .....Pukul 11.30-11.40.

$288 \mid$ JURNAL LISAN AL-HAL 
di hadapi ketika proses pembuatan produk seperti yang di paparkan oleh Rofi'ul Huda selaku pegawai produksi sablon bahwa:

"Dalam sebuah penerapan etika bisnis Islam pasti terdapat kendala yang harus dihadapi seperti ketika pembuatan sebuah produk sablon dengan desain yang baru dan cukup sulit menjadikan kita sering terjadi kesalahan dalam pembuatan meskipun bagi yang tidak memesan tidak akan tahu kesalahannya dimana, tetapi bagi yang memesan desain tersebut pasti mereka mengetahuinya, meskipun begitu kita tetap menjual hasil produk tersebut dengan harga yang lebih murah dengan konsumen yang berbeda. Bukan hanya itu dalam suatu bisnis pasti memiliki kendala dalm administrasi seperti danya hutang piutang yang dilakukan seorang konsumen menyulitkan kita dalam laporan pemasukan dan pengeluarannya." 42

Pendapat tersebut juga dipaparkan likah selaku konsumen $H C G$ (Hikma Collection Group) bahwa:

" saya takut ketika membeli hasil sablon yang tidak sesuai yang saya inginkan, tetapi jika di HCG (Hikma Collection Group) ini jika tidak sesuai dengan yang kita inginkan pasti dari pihak penjual memberitau saya telebih dahulu dan kemudian memberikan kesepakatan harga yang sesuai dengan kualitan barang yang kurang memuaskan." 43

Dari penjelasan hasil wawancara diatas dapat disimpulkan bahwa memberikan hasil produk dengan kualiatas yang sesuai dengan keinginan konsumen itu tidak mudah, membutuhkan kesabaran dan ketekunan untuk menghadapi hal tersebut. Serta penertiban suatu Administrasi juga memiliki suatu kendala ketika adanya hutang piutang dalam suatu transaksi.

Berdasarkan hasil wawancara dari beberapa informan dapat ditarik kesimpulan bahwa penerapan Etika Bisnis Islam dalam pengelolaan HCG (Hikma Collection Group) ini memiliki beberapa hambatan dan kendala yang harus dihadapi, seperti tidak adanya kesadaran diri terkait pentingnya etika dalam berbisnis, hutang piutang dalam penertiban administrasi, dan mendapat kepercayaan dalam memenuhi keinginan pelanggan dalam pembuatan suatu produk yang bermutu dan berkualitas.

42 Hasil Wawancara Dengan Rofi'ul Huda Selaku Pegawai Sablon HCG (Hikma Collection Group), Tanggal 19 Maret 2020, Pukul 09.00-09.20.

43 Hasil Wawancara Dengan Likah Selaku Konsumen Sablon Di HCG(Hikma Collection Group), Tanggal 19 Maret 2020, Pukul 12.00-12,10. 


\section{E. Analisis}

Etika dalam Islam diartikan sebagai moral, akhlak ataupun perilaku. Namun, akhlak yang dimaknai sebagai tindakan moral sering juga disepadankan dengan istilah etika. Sedangkan etika bisnis itu sendiri merupakan suatu kegiatan berbisnis yang menggunakan prinsip etika baik itu berkaitan dengan individu, perusahaan maupun masyarakat. Untuk etika bisnis yang sesuai dengan syari'at Islam, berarti etika berbisnis yang harus mengedepankan nilai-nilai syari'at seperti mengetahui perkara yang halal dan haram. Menurut pendapat muhammad djakfar sendiri terkait etika bisnis islam adalah norma-norma etika yang berbasiskan al-qur'an dan hadis yang menjadi acuan dalam berbisnis. ${ }^{44}$ Adapun landasan syari'ah etika berbisnis berdasarkan Al-Qur'an sebagai berikut: Al-Qur'an surat Al-Isro' Ayat 35 Allah Berfirman:

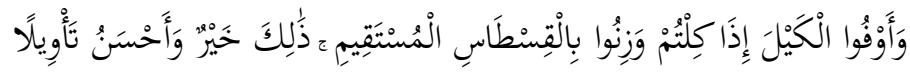

"Dan sempurnakanlah takaran apabila kamu menakar, dan timbanglah dengan neraca yang benar. Itulah yang lebih utama (bagimu) dan lebih baik akibatnya."(Al-Qur'an S. Al-Isro' : 35).45

Al-Qur'an surat Al-Kahfi Ayat 29 Allah Berfirman:

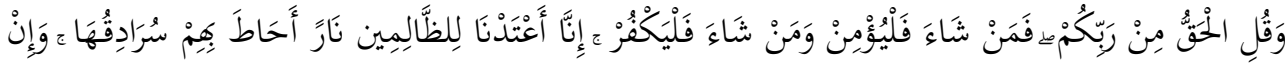

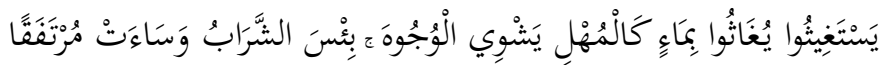

"Kebenaran itu datangnya dari Tuhanmu; maka barang siapa yang ingin (beriman) hendaklah ia beriman, dan barangsiapa yang ingin (kafir) biarlah ia kafir". Sesungguhnya Kami telah sediakan bagi orang orang zalim itu neraka, yang gejolaknya mengepung mereka. Dan jika mereka meminta minum, niscaya mereka akan diberi minum dengan air seperti besi yang mendidih yang menghanguskan muka. Itulah minuman yang paling buruk dan tempat istirahat yang paling jelek."(Al-Qur'an S. Al-Kahfi: 29).

Secara syari'ah, etika bisnis yang menggunakan Al-Qur'an ataupun hadis sebagai acuan seperti prinsip etika bisnis Islam yang dibuat oleh muhammad Djakfar ini memiliki tujuh prinsip yang baik untuk diterapkan dalam suatu bisnis yaitu kejujuran, menjual barang yang baik mutunya, tidak mengobral sumpah, bertanggung jawab dalam bisnis, bermurah hati, keseimbang dalam berbisnis, dan tertib administrasi. Prinsip ini

44 Muhammad Djakfar, Etika Bisnis: Menangkap Spirit Ajaran Langit dan Pesan Moral Ajaran Bumi, (Jakarta: Penebar Plus, 2012), 30. 2005), 76.

45 Departemen Agama RI, Al-Quran dan Terjamahnya, (Surabaya: CV. Karya Utama,

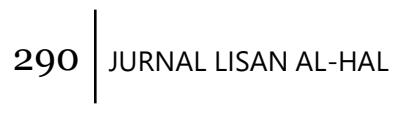


dimaksudkan bahwa sumber utama etika Islam adalah kepercayaan total dan murni terhadap kesatuan (keesaan) Tuhan. Penerapan etika bisnis Islam dalam suatu bisnis berarti menjalankan semua prinsip yang telah menjadi kebiasaan etika dalam beraktivitas.

Bisnis dalam Islam seperti HCG (Hikma Collection Group) memiliki tujuan yang akan dicapai yaitu mencapai nilai materi serta non materi seperti terciptanya suasana persaudaraan, kepedulian sosial dan sebagainya. Selain memiliki tujuan tersebut di HCG (Hikma Collection Group) juga memiliki target yang telah dicapai tidak dengan pertumbuhan setiap tahunnya harus dijaga keberlangsungannya agar perusahaan dapat exsis dalam kurun waktu yang lama. Untuk itu suatu etika sangat diperlukan dalam berbisnis.

Dalam prakteknya penerapan etika bisnis Islam dalam pengelolaan HCG (Hikma Collection Group) ini menggunakan beberapa prinsip, yang menggunakan delapan prinsip yang telah menjadi adat setiap harinya. Yang diterapkan menggunakan tujuh prinsip dari pendapat Muhammad Djakfar, dan peneliti menemukan satu prinsip di HCG (Hikma Collection Group) yang diluar dari teori etika bisnis Islam yang dimiliki Muhammad Djakfar yaitu menyelesaikan produk sesuai target yang diinginkan konsumen.

Dalam penerapan etika bisnis Islam di HCG (Hikma Collection Group) dapat dibuktikan dari hasil penelitian sebagai berikut:

Pertama, Kejujuran Dalam Berbisnis. Dalam menjalankan suatu bisnis dalam Islam dianjurkan untuk bersifat jujur, kejujuran bisnis di $H C G$ (Hikma Collection Group) dari proses produksi barang menggunakan bahan yang sesuai dengan yang diinginkan konsumen serta mengukur bahan yang dibutuhkan dalam pembuatan barang. Serta jujur dalam berperilaku dan bertransaksi kepada konsumen.

Kedua, Menjual Barang Yang Baik Mutunya. Barang yang digunakan untuk memproduksi hasil sablon maupun jahitan ini sesuai dengan keinginan konsumen, dan di HCG (Hikma Collection Group) selalu menggunakan barang yang berkualitas baik serta dari bahan yang halah untuk dikonsumsi konsumen. Karena setiap pegawai mengutamakan petunjuk syari'at Islam terkait berniaga antara manusia dengan Allah serta kepuasan pelanggan yang selalu menjadi prioritas produk HCG (Hikma Collection Group).

Ketiga, Tidak Mengobral Janji. Dalam penjualan barang yang dihasilkan di HCG (Hikma Collection Group) sesuai dengan kualitas harga dan mutu barang yang dihasilan tidak pernah mengobral janji untuk meyakinkan konsumen untuk membeli. Jika memang kualitas barang yang 
dijual belikan kurang baik maka barang tersebut akan dijual dengan harga di bawah harga normal. Dari pihak HCG (Hikma Collection Group) tidak pernah memaksa konsumen untuk membeli produk barang yang diperjualkan tetapi tujuan utama hanya ingin memenuhi kebutuhan konsumen dan pastinya mendapat laba sesuai standart syari'at Islam.

Keempat. Bertanggungjawab Dalam Berbisnis. Sifat tanggungjawab dalam berbisnis di HCG (Hikma Collection Group) telah diterapkan dalam berbisnis artinya bertanggungjawab terkait ketidakpuasan dihadapan kosumen saja itu tidak cukup, melainkan bertanggungjawab dihadapan Allah Swt, hal ini dibuktikan dengan tidak adanya transaksi-transaksi kecurangan yang diterapkan di HCG (Hikma Collection Group), seperti tidak adanya riba, ghoror dan lain-lain.

Kelima, Tidak Mengikat dan Bermurah Hati. Di HCG (Hikma Collection Group) setiap pegawai selalu bersikap tidak mengikat dan bermurah hati kepada semua pelanggan dan kepada sesama karyawan lainnya, sikap senyum, sopan, salam, dan ramah terhadap sesama pegawai dan konsumen telah menjadi kebiasan kerja di HCG (Hikma Collection Group). Maka tidak heran jika banyak konsumen yang tertarik untuk membeli produk-produk yang ditawarkannya.

Keenam, Keseimbangan berbisnis. Keseimbangan dalam berbisnis yang telah diterapkan di HCG (Hikma Collection Group) selain berproduksi dan bekerja memenuhi keinginan konsumen juga diterapkan kegiatan religius seperti jama'ah bersama, mengeluarkan zakat setelah pembuatan saldo akhir, dan nasehat tentang agama dari pengasuh. Hal tersebut dilakukan untuk membentuk hidup yang seimbang, artinya tidak hanya memikirkan urusan duniawi saja melainkan akhirat juga diperlukan.

Ketujuh, Tertib Administrasi. Di HCG (Hikma Collection Group) selalu mengadakan pembacaan laporan akhir pertanggungjawaban keuanggan setiap satu tahun sekali, hal ini dibuktikan adanya buku-buku laporan pertanggungjawaban administrasi (LPJ) setiap tahun mulai dibentuknya bisnis konveksi ini sampai sekarang.

Selain dari ketujuh prinsip dari Djakfar yang digunakan di $H C G$ (Hikma Collection Group) memiliki satu prinsip yang diluar dari teori yaitu menyelesaikan produk sesuai target yang diinginkan konsumen, prinsip ini menjadi prinsip utama di HCG (Hikma Collection Group) karena kebanyakan dari bisnis konveksi itu hanya mengobral janji kepada konsumen, banyak yang menerima pesanan tetapi tidak bisa menempati janjinya sesuai target yang diinginkan konsumen. Di HCG (Hikma Collection Group) jika tidak sanggup memenuhi keinginan konsumen

$292 \mid$ JURNAL LISAN AL-HAL 
sesuai yang ditentukannya lebih baik menolaknya, dari pada nanti akan mengecewakan konsumen.

Penerapan etika bisnis Islam di HCG (Hikma Collection Group) memiliki kebiasaan kerja yang dapat mendukung penerapan etika bisnis tersebut, seperti kebiasaan di bawah ini: 1) Berdo'a bersama setiap akan bekerja setiap pagi hari, 2) Selalu jujur dalam melaksanakan tugas dan pekerjaannya, 3) Tidak melanggar peraturan pondok pesantren, 4) Semua karyawan Wajib mengikuti kegiatan di pondok pesantren, 5) Bekerja propesional sesuai dengan tugas dan kewajiban masing-masing, 6) Bersikap ramah dalam melayani semua pelanggan, 7) Rela berjuang dan berkorban ketika terjadi resiko bisnis dengan iklas untuk mendapat ridho allah, 8) Berbuat baik terhadap pelanggan saat menghutang, 9) Dilarang menggunakan sumpah untuk menarik pelanggan, 10) Menjalin keharmonisan dan kekeluargaan terhadap semua karyawan, 11) Penggadaan musyawaroh kerja setiap akhir bulan, 12) Ketua bertanggungjawab terhadap keputusan yang telah disepakati bersama, dan 13) Memberikan penghargaan terhadap pegawai yang menyelesaikan pekerjaan dengan baik.

Penerapan etika bisnis Islam yang dilakuakan di HCG (Hikma Collection Group) berpegang teguh menggunakan prinsip bermuamalah yang diajarkan oleh Islam, karena banyaknya ilmu pengetahuan serta tauhid yang kuat terkait syari'at islam yang dimiliki dari masing-masing pegawai.

Dalam suatu bisnis memiliki faktor pendukung dalam menerapkan etika bisnis Islam. Faktor pendukung adalah suatu keadaan yang dapat membentuk perilaku yang sesuai dengan bisnis Islam. Terkait faktor pembentukan prilaku, Nilai perilaku dapat diibaratkan sebagai software, supaya perilaku dapat diamati, dihayati dan diaktualisasikan. Seperti dari teori seorang ahli etika bisnis Islam dari Amerika, Rafiq Issa Beekun mengungkapkan bahwa perilaku etika individu dapat dipengaruhi oleh 3 (tiga) faktor, yaitu faktor interpretasi terhadap hukum artinya manusia perlu menafsirkan terhadap hukum bahwa hukum itu melindungi segenap jiwa dan raga manusia dari berbagai faktor yang menghilangkan eksistensi manusia. Yang kedua faktor Lingkungan artinya manusia akan dengan mudah merekam setiap aktivitas yang terjadi di lingkungannya yang lambat laun akan membentuk pola tingkah laku bagi kehidupannya di masa yang akan datang. Dan faktor ketiga yaitu faktor individu artinya suatu kesadaran diri terkait etika bisnis Islam yang akan menguji standar Iman seorang muslim. Dari teori tersebut peneliti melakukan analisis di HCG (Hikma Collection Group) terkait faktor yang mendukung penerapan 
etika bisnis Islam yang mendapatkan beberapa faktor yang sesuai dengan teori Rafiq Issa Beekun dengan Tiga Faktor serta buktinya sebagai berikut: 1. Faktor interpretasi terhadap hukum

Dalam Islam hukum terkait berbisnis dan bertransaksi telah dijelaskan secara terperinci, penerapan etika bisnis Islam ini dengan mudah diterapkan di HCG (Hikma Collection Group) karena disini telah dibentuk beberapa peraturan sesuai dengan hukum Islam seperti adanya sifat kejujuran dalam berproduksi dan penjualan prodak terhadap konsumen sccara ramah dan trasparan, hal ini dilakukan agar tidak ada salah satu pihak yang merasa dirugikan.

2. Faktor lingkungan

Faktor lingkungan sangat berpengaruh di HCG (Hikma Collection Group) karena lingkungan yang agamis seperti di bawah naungan pondok pesantren ini menjadi pendukung yang sangat kuat, kerena setiap kegiatan produksi pasti akan menyesuaikan kegiatan pondok pesanteran artinya pegawai harus mematuhi peraturan pondok pesantren, kegiatan tersebut seperti mengaji, berjamaah dan lain sebagainya yang dapat membentuk karakter pegawai di HCG (Hikma Collection Group) sesuai dengan etika berbisnis yang sesuai agama Islam.

3. Faktor individu

Selain dari kedua faktor diatas faktor individu menjadi faktor utama pendukung penerapan etika bisnis Islam di HCG (Hikma Collection Group), karena yang dapat merubah sikap dan karakter seseorang itu dari kesadaran diri sendiri, usaha di HCG (Hikma Collection Group) untuk membentuk kesadaran diri yaitu seperti pengarahan ketua setiap satu minggu sekali, dan nasehat setiap satu bulan sekali kepada semua karyawan.

Selain faktor pendukung penerapan etika bisnis Islam di dunia bisnis memiliki sebuah hambatan dalam penerapannya. Seperti teori yang dikeluarkan oleh Keraf memiliki lima kendala yaitu standar moral yang masih lema artinya menghalalkan segala cara untuk memperoleh keuntungan untuk mendapat keuntungan, tidak memiliki kesadaran diri dalam menjalankan suatu peraturan artinya Kesadaran dalam diri seseorang sangat diperlukan dalam penerapan suatu moral atau etika dalam berbisnis, lemahnya penegakan hukum artinya Banyaknya orang yang sudah melanggar dan bersalah dalam perilaku moral dalam berbisnis yang dibiarkan dan tetap memangku jabatannya di sebuah bisnis tersebut, tidak adanya sebuah kepercayaan artinya kepercayaan dalam proses pembangunan dan pengembangan suatu usaha, banyak seorang konsumen

$294 \mid$ JURNAL LISAN AL-HAL 
yang kurang percaya dalam proses dan hasil produk yang dibuat oleh produsen dan hutang piutang dalam sebuah transaksi hambatan dalam pengelolaan bisnis baik nanti dalam segi produksi maupun dalam pembuatan laporan administrasi pada akhir tahun. Tetapi dari kelima teori tersebut hanya terdapat tiga kendala yang dialami di HCG (Hikma Collection Group) tersebut, yaitu tidak adanya kesadaran diri, hutang piutang dalam penertipan administrasi, dan kepercayaan pelanggan. Hal ini dapt dibuktikan sebagai berikut:

1) Tidak Memiliki kesadaran diri. Hal ini terjadi karena banyaknya karyawan yang berusia remaja yaitu dari para santri, jadi pola fikirnya ingin selalu bermain dan belum memiliki pemikiran yang dewasa.

2) Hutang Piutang Dalam Penertipan Administrasi. Dalam sebuah transaksi jual beli pasti terdapat permasalahan terutama menghadapi konsumen yang menghutang. Di HCG (Hikma Collection Group) setiap tahunnya memiliki laporan keuangan sendiri. Kesulitan dalam membuatnya karena adanya transaksi hutang piutang konsumen yang terkadang sudah jatuh tempo belum dibayar

3) Kepercayaan Pelanggan. Dalam menjalankan bisnis pasti membutuhkan kepercayaan pelanggan. Di HCG (Hikma Collection Group) memiliki produk yang baik tetapi karena banyaknya produk yang sama dan namanya lebih terkenal dari yang lain, makanya cukup sulit untuk mendapat kepercayaan pelanggan. Meskipun demikian tetapi HCG (Hikma Collection Group) tetap memberikan produkproduk yang berkualitas.

Dalam pelaksanaan etika bisnis Islam di HCG (Hikma Collection Group) menggunakan prinsip syari'ah untuk semua pegawai yang memiliki wawasan agama Islam yang luas dari pondok pesantren Miftahul Hikmah, serta mengutamakan bermuamalah sesuai ajaran Islam dengan adanya iman yang kuat dari masing-masing pegawai.

\section{F. Simpulan}

Dari hasil penelitian yang berjudul implementasi etika bisnis syari'ah dalam pengelolaan HCG (Hikma Collection Group) di pondok pesantren miftahul hikmah parengan tuban dapat di simpulkan sebagai berikut: Implementasi etika bisnis Islam dalam pengelolaan HCG (Hikma Collection Group) yang berada dibawah naungan pondok pesantren ini menggunakan delapan prinsip yang sesuai dengan ajaran Islam yaitu yang pertama dengan prinsip kejujuran dalam berbisnis, kejujuran bisnis di HCG (Hikma Collection Group) dari proses produksi barang menggunakan bahan yang sesuai dengan yang diinginkan konsumen serta mengukur 
bahan yang dibutuhkan dalam pembuatan barang. Serta jujur dalam berperilaku dan bertransaksi kepada konsumen. Yang kedua dengan prinsip menjual barang yang baik mutunya, memproduksi hasil sablon maupun jahitan di HCG (Hikma Collection Group) ini sesuai dengan keinginan konsumen dengan kualitas bahan yang baik dan halal menurut ajaran Islam. Prinsip ketiga yaitu, tidak mengobral janji kepada konsumen yang ingin membeli di HCG (Hikma Collection Group) artinya tidak akan mengunggulkan hasil produksi yang tidak sesuai dengan kualitas barang. Prinsip keempat yang diterapkan di HCG (Hikma Collection Group) bertanggungjawab dalam berbisnis terkait ketidakpuasa dihadapan konsumen dan bertanggungjawab dihadapan Allah, seperti adanya rutinitas solat berjama'ah serta kegiatan religius yang lain seperti do'a bersama dan mauidhoh dari pengasuh pondok pesantren. Prinsip kelima yaitu tidak mengikat dan murah hati kepada pelanggan dan semua pegawai dengan membiasakan sikap sopan, senyum, salam dan ramah terhadap semua konsumen dan masing-masing karyawan.prinsip keenam keseimbangan berbisnis dengan cara selalu mngutamakan ketauhidan setiap karyawan di HCG (Hikma Collection Group). Prinsip ketujuh tertib dalam administrasi yang menggunakan kejujuran dan ketepatan waktu dalam menyelesaikan laporan administrasi. Prinsip yang terakhir yaitu menyelesaikan produk sesuai target yang diinginkan konsumen. Jika tidak bisa menyelesaikan produk yang diinginkan sesuai dengan deadline maka dari pihak HCG (Hikma Collection Group) akan menolak peasanan tersebut.

Faktor pendukung dalam penerapan etika bisnis Islam di HCG (Hikma Collection Group) memiliki tiga faktor pendung yaitu, faktor interpretasi terhadap hukum diwujudkan dengan adanya kesadaran terkait peraturan yang sesuai dengan Islam, seperti pentinya kejujuran dalam bekerja serta penjualan yang transparan. Faktor yang kedua yaitu faktor lingkungan, di HCG (Hikma Collection Group) sangat mendukung dari faktor externalnya karena berada dibawah naungan pondok pesantren dan lingkungan yang religius. Hal ini terbukti adanya solat berjama'ah setiap hari dan mauidhoh dari pengasuh untuk menasehati semua karyawan. Faktor ketiga yaitu dari faktor individu, faktor ini diukur dari tingkat ketauhidan masing-masing karyawan, di HCG (Hikma Collection Group) memiliki karyawan dari para santri dengan memiliki bekal ilmu agama yang luas, akan menguatkan Aqidahnya. Selain dari faktor pendukung dalam penerapan Etika bisnis Islam di HCG (Hikma Collection Group) ini memiliki hambatan dalam menerapkan etika bisnis Islam seperti kurang adanya kesadaran diri dari masing-masing karyawan.

296 JURNAL LISAN AL-HAL 
Karena karyawan yang masih remaja dengan pola fikir yang berubah-ubah memerlukan perhatian yang lebih dari ketua untuk selalu mengontrolnya. Hambatan yang kedua berupa adanya transaksi hutang piutang yang muncul ketika proses jual-beli ini menyulitkan untuk membuat laporan keuangan setiap bulannya. Selanjutnya hambatan yang terakhir yang di alami di HCG (Hikma Collection Group) yaitu dengan sulitnya mendapatkan kepercayaan pelanggan, karena produk yang dihasilkan di HCG (Hikma Collection Group) tergolong produksi konveksi baru, sehingga kalah dengan usaha konveksi rumahan yang sudah lama berdiri dan terkenal di masyarakat disekitarnya.

\section{DAFTAR PUSTAKA}

Alma, Buchari dan Priansa, Donni Juni. Manajemen Bisnis Syariah Bandung: Alfabeta, 2009.

Asy'arie, Musa. Islam: Etika \& Konspirasi Bisnis, Yogyakarta: Lembaga Studi Filsafat Islam (LESFI), 2016.

Badroen, Faisal. Etika Bisnis dalam Islam. Jakarta: Kencana, 2006.

Departemen Agama RI, Al-Quran dan Terjamahnya, Surabaya: CV. Karya Utama, 2005.

Djakfar, Muhammad. Etika Bisnis: Menangkap Spirit Ajaran Langit dan Pesan Moral Ajaran Bumi, Jakarta: Penebar Plus, 2012.

Fauzia, Ika Yunia. Etika Bisnis dalam Islam, Jakarta: Prenada media Group, 2013.

Haider Naqvi, Syed Nawab. Menggagas Ilmu Ekonomi Islam terj. M. Saiful Anam dan Muhammad Ufuqul Mubin. Yogyakarta: Pustaka Pelajar, 2003.

Hasan, Ali. Manajemen Bisnis Syari'ah (Yogyakarta: Pustaka Pelajar, 2009)

Hasan, M. Iqbal. Pokok-Pokok Materi Metode Penelitian dan Aplikasinya. Jakarta: Ghalia Indonesia, 2002.

Hasil Wawancara Dengan Azizah Selaku Konsumen Di HCG (Hikma Collection Group), Tanggal 20 Maret 2020, Pukul 10.30-11.00.

Hasil Wawancara Dengan Khamim Selaku Pegawai HCG (Hikma Collection Group) Dan Santri Pondok Pesantren Miftahul Hikmah, Tanggal 18 Maret 2020, Pukul 13.00-13.30.

Hasil Wawancara Dengan Likah Selaku Konsumen Sablon Di HCG(Hikma Collection Group), Tanggal 19 Maret 2020, Pukul 12.00-12,10.

Hasil Wawancara Dengan Pengasuh Pondok Pesantren Miftahul Hikmah, Tanggal 18 Maret 2020, Pukul 13.30-13.45.

Hasil Wawancara Dengan Rofi'ul Huda Selaku Pegawai Sablon HCG (Hikma Collection Group), Tanggal 19 Maret 2020, Pukul 09.00-09.20. 
Hasil Wawancara Dengan Sulainah Selaku Penasehat HCG (Hikma Collection Group), Tanggal 19 Maret 2020, Pukul 08.00-09.00.

Hasil Wawancara Dengan Sutikno Selaku Ketua HCG (Hikma Collection Group), Tanggal 18 Mater 2020, Pukul 10.30-11.00.

Hasil Wawancara Dengan Sutikno Selaku Ketua HCG (Hikma Collection Group), Tanggal 18 Maret 2020, Pukul 11.00-11.30.

Hasil Wawancara Dengan Zainal Selaku Konsumen Di HCG (Hikma Collection Group), Tanggal 20 Maret 2020, Pukul 13.00-13.30.

Hasil Wawancara kepada ketua HCG (Hikma Collection Group) Miftahul Hikmah sokorejo, parengan, Tuban, Jum'at 19 Desember 2019, Pukul 10.00-10.30.

Hasil Wawancara Kepada Nuriah Selaku Konsumen Di HCG (Hikma Collection Group), Tanggal 20 Maret 2020, Pukul 15.00-15.30.

Hasil Wawancara Kepada Pengasuh Dan Pendiri Pondok Pesantren Miftahul Hikmah, Tanggal 18 Maret 2020, Pukul 13.00-13.30.

Hidayat, Dany. Pencapaian Maslahah Melalui Etika Bisnis Islam Studi Kasus Restoran Mie Akhirat. Jurnal JESTT, Vol. 2, No. 11. 2015.

Lexy J. Moleong, Metodologi Penelitian Kualitatif. Bandung: PT. Remaja Rosdakarya, 2005.

Margono, Metodologi Penelitian. Jakarta: Ghalia Indonesia, 1998.

Muhammad dan Alimin, Etika \& Perlindungan Konsumen dalam Ekonomi Islam. Yogyakarta: BPFE, 2004.

Muhammad dan Fauroni, R. Lukman. Visi Al-Qur'an tentang Etika dan Bisnis. Jakarta: Salemba Diniyah, 2002.

Nasution, Metode Penelitian Naturalistik-Kualitatif. Bandung: Tarsito, 2002.

Nur Zaroni, Akhmad. Bisnis Dalam Perspektif Islam. Telaah Aspek Keagamaan dalam Kehidupan Ekonomi, Mazahib Vol. IV, No. 2, Desember 2007.

Rivai, Veithzal dan Usman, Antoni Nizar. Islamic Economics and Finance: Ekonomi dan Keuangan Islam Bukan Alternatif, tetapi Solusi. Jakarta: Gramedia Pustaka Utama, 2012.

Rivai, Veithzal Zainal, dkk. Islamic Marketing Management, Jakarta: PT. Bumi Aksara, 2017.

Rivai, Veithzal, Nuruddin, Amiur dan Arfa, Faisar Ananda. Islamic Business and Economic Ethics. Jakarta: Bumi Aksara, 2012.

S. Margono, Metodologi Penelitian. Jakarta: PT. Rineka Cipta, 2000.

Solihin, Ismail. Pengantar Bisnis: Pengenalan Praktik dan Studi Kasus, Jakarta: Kencana, 2006.

298 JURNAL LISAN AL-HAL 
Sudjana, Nana dan Ibrahim, Penelitian dan Penelitian Pendidikan. Bandung: Sinar Baru, 1989.

Tim DPPAI, Pilar Substansial Islam, Cetakan Ketiga, DPPAI UII, Yogyakarta, 2016.

Wahid, Abdurrahman. Menggerakkan Tradisi. Yogyakarta: LKis, 2001. 
"Etika Bisnis Pengelolaan HCG"

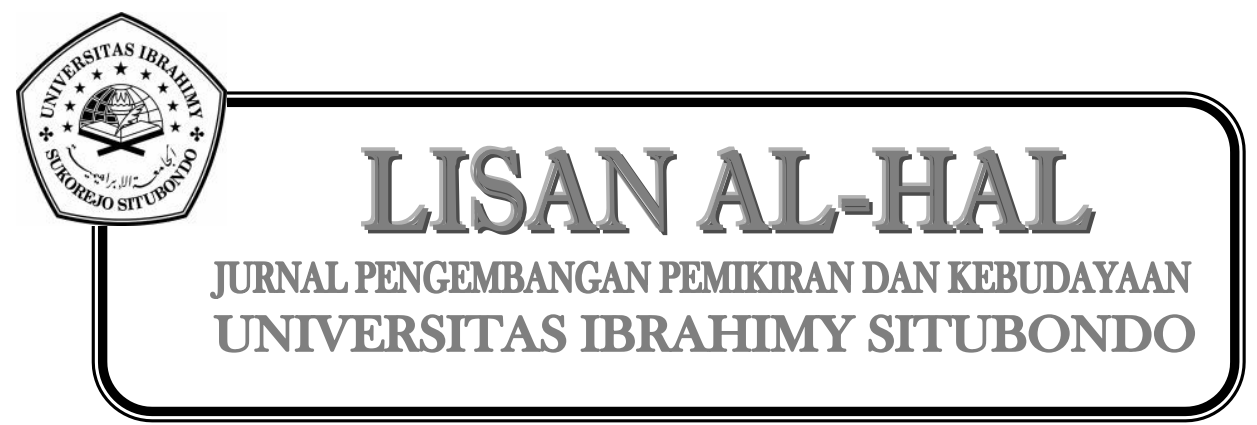

300 JURNAL LISAN AL-HAL 